\title{
PHOSPHORUS AND SILICON IN SEA WATER OFF PLYMOUTH DURING 1954
}

\author{
By F. A. J. Armstrong \\ The Plymouth Laboratory
}

(Text-figṣ. I-4)

Analyses of water collected during I954 at the International Hydrographic Station E I (lat. $50^{\circ} 02^{\prime} \mathrm{N}$., long. $4^{\circ} 22^{\prime} \mathrm{W}$.) are here reported in the same form as in a previous report (Armstrong, 1954). The methods of collection and analysis of samples were unchanged.

There are no observations below $30 \mathrm{~m}$. at the end of the year because of a mishap with the sampling gear in November, and because bad weather curtailed work at sea in December.

\section{Temperature AND SALINITY}

The vertical distribution of temperature during the year is shown in Fig. I. The water column showed vertical uniformity until May. The minimum surface temperature recorded was 9.0 on I2 March. The mean salinity increased between I9 January and I6 February from $35 \cdot 31$ to $35 \cdot 37$. The significance of this small change is discussed below. On Io May, after rough weather there was only $0.5^{\circ} \mathrm{C}$. difference between the top and bottom of the water column, but on I9 May the difference was $2.3^{\circ} \mathrm{C}$ and there was a marked thermocline at $30 \mathrm{~m}$. This thermocline remained at 25 to $30 \mathrm{~m}$ during the summer, but had broken down by II October. Summer temperatures in the upper layers were unusually low, the surface maximum of $14.92^{\circ} \mathrm{C}$ being recorded on I4 September. The observations for II August and I4 September are given in full in Table I, from which it may be seen that marked temperature increases took place. Those in the deeper water are larger than in the upper layers and cannot be put down to vertical mixing. The sharpness of the thermocline remains unimpaired. A small but significant increase in salinity occurred. The weather records from Mount Batten Station show that mean air temperatures (at Plymouth) in the interval lay between the sea surface temperatures at E I observed on II August and I4 September, and that hours of sunshine were a little less than average. Although direct absorption of solar radiation causes some warming of the sea surface irrespective of the temperature of the air, it is improbable that the observed rises in temperature throughout the water column could have occurred locally. The change therefore must have been caused by a displacement of water masses on a considerable scale. 


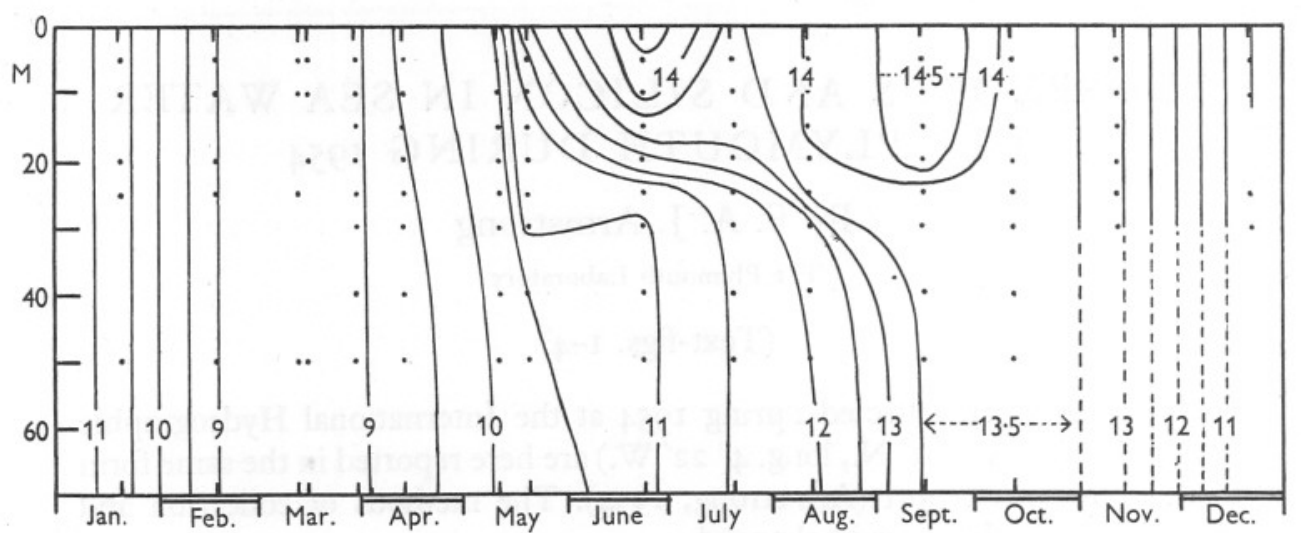

Fig. I. Vertical temperature distribution at International Hydrographic Station E I, 1954. Contour lines at $0.5^{\circ} \mathrm{C}$ intervals.

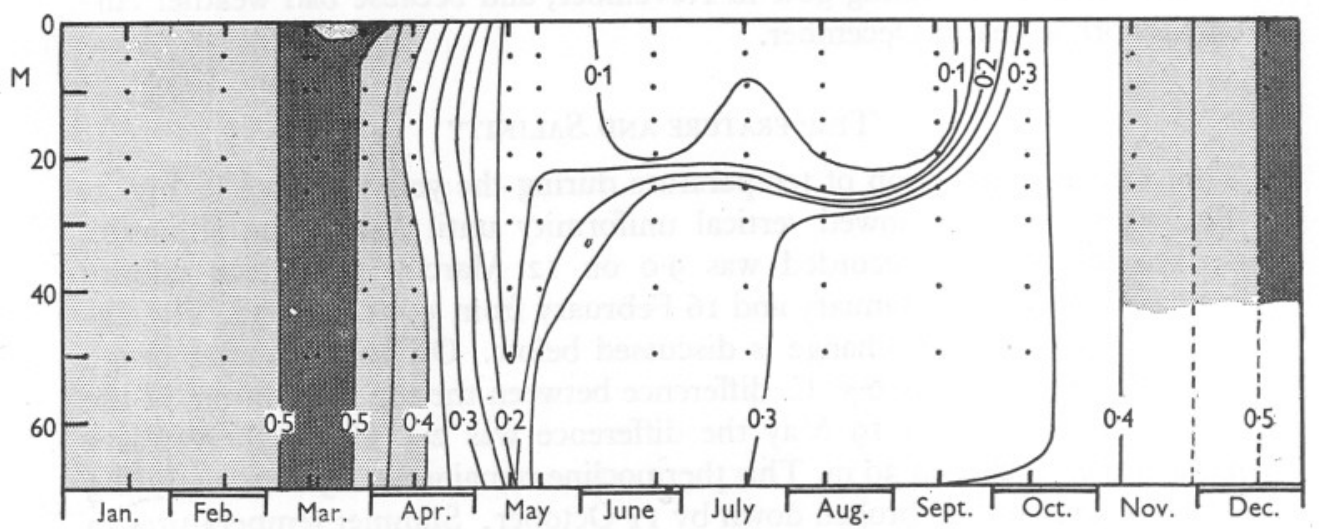

Fig. 2. Vertical distribution of phosphate as $\mu \mathrm{g}$ atom $\mathrm{P} / \mathrm{l}$. at International Hydrographic Station EI, I954. Contour lines at $0.05 \mu \mathrm{g}$ atom $\mathrm{P} / 1$. intervals.

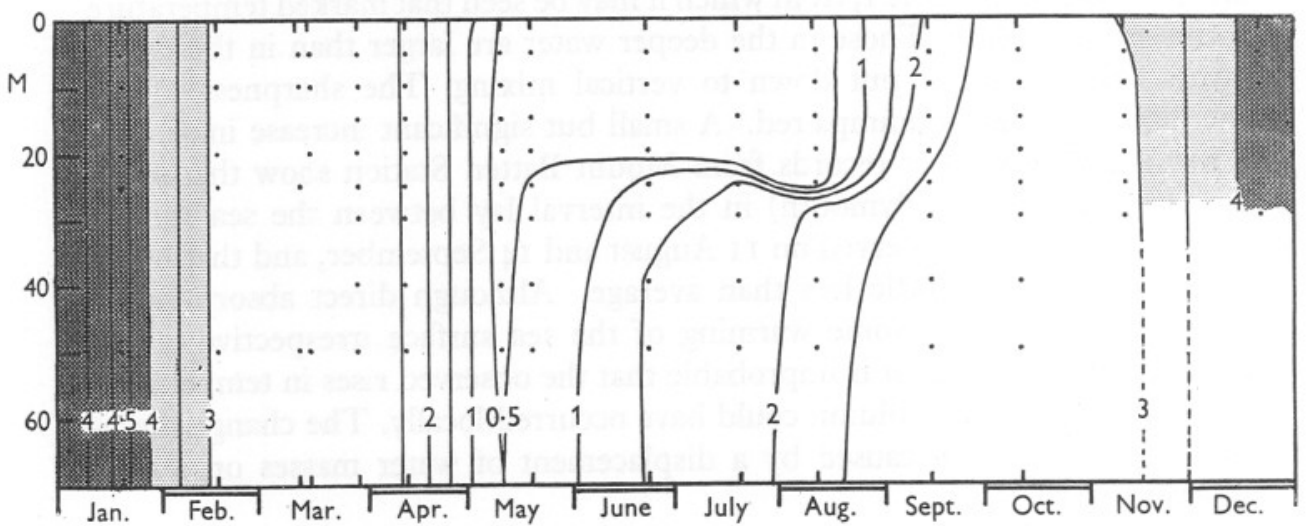

Fig. 3. Vertical distribution of silicate as $\mu \mathrm{g}$ atom $\mathrm{Si} / 1$. at International Hydrographic Station E I, I954. Contour lines at $0.5 \mu \mathrm{g}$ atom Si $/ 1$. intervals. 
During the whole of this period of 34 days a weak south-westerly air stream flowed over the area, becoming a strong south-westerly breeze (18-26 knots) for 2 days on 9-1o September. The weather remained cool and remarkably equable. The mean temperatures with standard deviations were

$\begin{array}{ll}\text { Max. day temp. } & 17 \cdot 3 \pm 1 \cdot 3^{\circ} \mathrm{C} \\ \text { Min. night temp. } & 12 \cdot 0 \pm 2 \cdot 0^{\circ} \mathrm{C} \\ \text { Overall mean } & 14 \cdot 7^{\circ} \mathrm{C}\end{array}$

Mean hours of sunshine were $5.46 \mathrm{~h} /$ day. The average for this period is estimated as about 5.9.

After the breakdown of the thermocline, temperatures decreased as is normal. On 2I December the upper Io $\mathrm{m}$. was colder and less saline than at 25 and $30 \mathrm{~m}$ (e.g. $5 \mathrm{~m} \mathrm{10} \cdot 48^{\circ} \mathrm{C}, 34 \cdot 76 \%$ S; $25 \mathrm{~m} \mathrm{II} \cdot 07^{\circ} \mathrm{C}, 35 \cdot 10 \%$ S) which suggests the presence of coastal water after the heavy rainfall of late November and early December.

\section{Table I. Temperature and Salinity at International Hydrographic Station E i, in August and I4 September I954}

\begin{tabular}{|c|c|c|c|c|}
\hline \multirow{2}{*}{$\begin{array}{c}\text { Depth } \\
\text { (m) }\end{array}$} & \multicolumn{2}{|c|}{ Temperature $\left({ }^{\circ} \mathrm{C}\right)$} & \multicolumn{2}{|c|}{ Salinity $(\%)$} \\
\hline & II Aug. & I4 Sept. & II Aug. & I4 Sept. \\
\hline 0.5 & 14.05 & $\begin{array}{l}14.92 \\
\end{array}$ & $35 \cdot 24$ & $35 \cdot 25$ \\
\hline & 14.05 & 14.87 & $35 \cdot 21$ & $35 \cdot 25$ \\
\hline Io & 14.05 & I4.87 & $35 \cdot 24$ & $35 \cdot 27$ \\
\hline I5 & 14.03 & I4.87 & $35 \cdot 24$ & $35 \cdot 27$ \\
\hline 20 & 13.99 & I4.77 & 35.25 & $35 \cdot 27$ \\
\hline 25 & 13.98 & 13.70 & 35.25 & $35 \cdot 30$ \\
\hline 30 & $12 \cdot 38$ & 13.59 & 35.29 & $35 \cdot 35$ \\
\hline 40 & $12 \cdot 22$ & 13.57 & $35 \cdot 30$ & $35 \cdot 35$ \\
\hline 50 & $12 \cdot 00$ & 13.54 & $35 \cdot 29$ & $35 \cdot 35$ \\
\hline 70 & II $\cdot 9 \mathrm{I}$ & 13.53 & $35 \cdot 33$ & $35 \cdot 33$ \\
\hline
\end{tabular}

\section{Phosphate}

The vertical distribution of phosphate is shown in Fig. 2, and values at Io and $50 \mathrm{~m}$ in Fig. 4. The water column was vertically almost homogeneous until early May. There was no significant change between I9 January and I6 February. During April phosphate concentrations fell sharply, and on Io May were low throughout the water column. It is reasonable to assume that the vertical mixing possible before the establishment of the thermocline had carried part of the phytoplankton crop below the photosynthetic zone. After I9 May when the thermocline restricted vertical movement of water, this part of the phytoplankton would be trapped at depths where it could not long survive for lack of light. The consequence is interesting. Above the thermocline phosphate remained low (minimum $0.07 \mu \mathrm{g}$ atom P/1. on II August), but at deeper levels it increased, presumably by regeneration from the dying phytoplankton.

By II October, when the water had become isothermal, phosphate also became uniform, and increased until the end of the year. 


\section{Silicate}

The vertical distribution of silicate is shown in Fig. 3 and values at 10 and $50 \mathrm{~m}$ in Fig. 4.

On I9 January silicate was $4.7 \mu \mathrm{g}$ atom Si/1., a little higher than in December I953, and the highest value recorded here since the present series of observations began in I950. On I6 February the concentration was $2 \cdot 8 \mu \mathrm{g}$ atom Si/1.

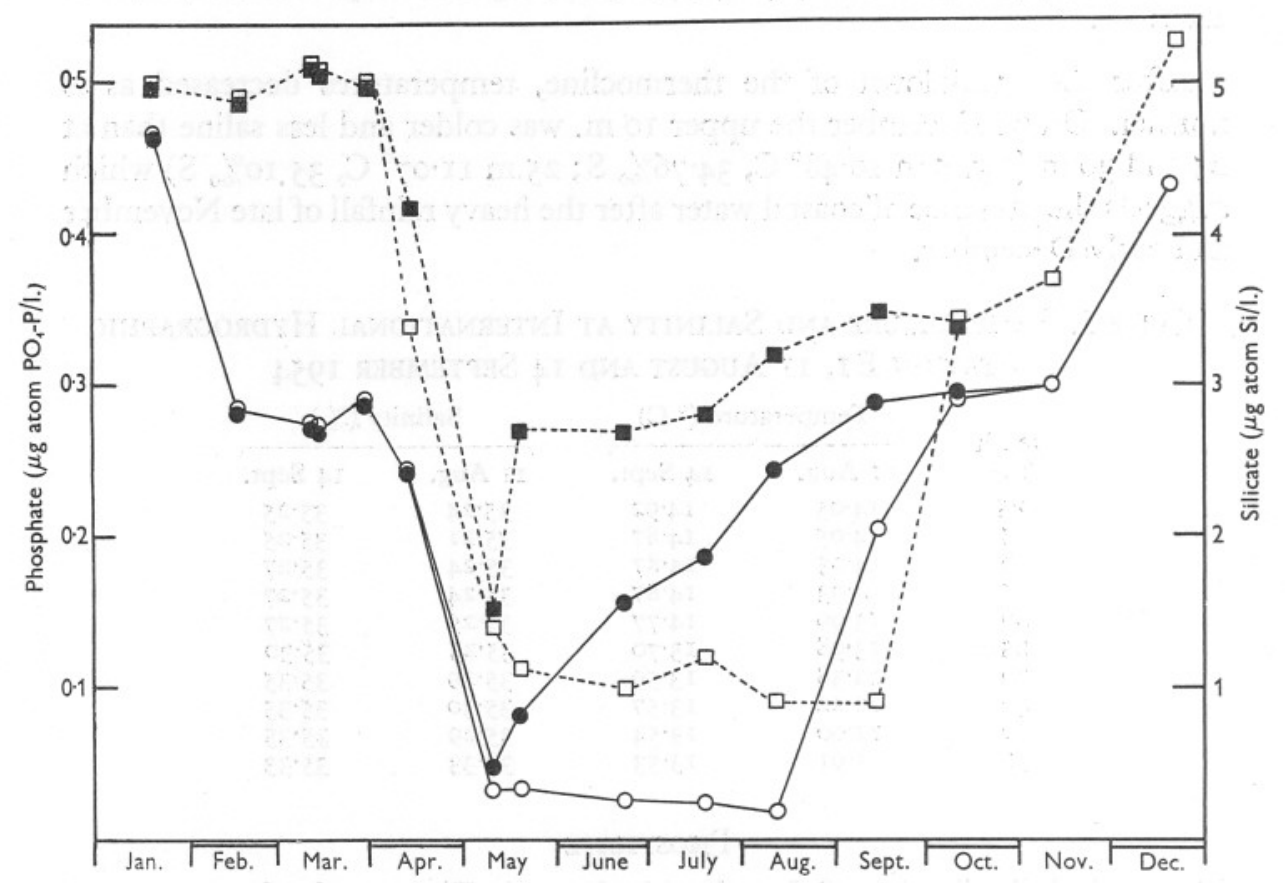

Fig. 4. Phosphate ( $\mu \mathrm{g}$ atom $\mathrm{PO}_{4}-\mathrm{P} / 1$.) and silicate $(\mu \mathrm{g}$ atom $\mathrm{Si} / \mathrm{l}$.) at ro and $50 \mathrm{~m}$ at International Hydrographic Station EI during I954. Phosphate at $10 \mathrm{~m}, \square$; at $50 \mathrm{~m}$, $\mathbf{0}$. Silicate at $\mathrm{IO} \mathrm{m}, \mathrm{O}$; at $50 \mathrm{~m}$,

This very large decrease cannot have been caused by growth of diatoms. Such a growth would have been unprecedented at this time of the year, but is ruled out of account since there was no corresponding decrease in phosphate. The change in silicate must be ascribed to an influx of another body of water. There was, as noted above, a small change in salinity.

Silicate values fluctuated somewhat until I2 April, when the mean value was 2.5 . On Io May this had fallen to 0.4 when phosphate had also diminished throughout the water column. After the establishment of the thermocline, silicate remained low in the upper layers (minimum value $0.17 \mu \mathrm{g}$ atom $\mathrm{Si} / 1$. on II August) though not so low as in I953. Below the thermocline there was a steady increase, more gradual than that for phosphate. The values at $50 \mathrm{~m}$ in 
Fig. 4 show an almost linear increase with time, which suggests that silica was dissolving from the frustules of diatoms trapped and dying below the euphotic zone.

On I4 September silicate had risen to $2 \cdot \mathrm{I} \mu \mathrm{g}$ atom Si/l. in the upper layers, although phosphate remained low. The possibility that diatoms may have been supplanted by non-siliceous algae cannot be excluded, though without more knowledge of the flora at this station this is speculative. It seems certain, considering the marked temperature change and the appreciable alteration in salinity, that there was a change in the water mass. Silicate concentrations increased further in November and December and high values around $4.3 \mu \mathrm{g}$ atom $\mathrm{Si} / \mathrm{l}$. were found in the top Io $\mathrm{m}$ layer on 2I December.

\section{Table II. Integral Mean Concentrations in Water Column at Station E I}

\begin{tabular}{|c|c|c|c|}
\hline Date & $\begin{array}{l}\text { Phosphate-P } \\
(\mu \text { g atom P/l.) }\end{array}$ & $\begin{array}{c}\text { 'Total-P' } \\
(\mu \mathrm{g} \text { atom } \mathrm{P} / \mathrm{l} .)\end{array}$ & $\begin{array}{c}\text { Silicate } \\
(\mu \mathrm{g} \text { atom } \mathrm{Si} / 1 .)\end{array}$ \\
\hline I9. i. 54 & $\begin{array}{l}0.50 \\
0.49\end{array}$ & $\begin{array}{l}0.57 \\
0.61\end{array}$ & $\begin{array}{l}4.70 \\
2.83\end{array}$ \\
\hline I6. ii. 54 & 0.49 & 0.61 & $2 \cdot 83$ \\
\hline I2. iii. 54 & $0.5 \mathrm{I}$ & 0.61 & $2 \cdot 74$ \\
\hline I5. iii. 54 & 0.51 & 0.62 & $2 \cdot 62$ \\
\hline 29. iii. 54 & 0.49 & 0.62 & $2 \cdot 88$ \\
\hline I2. iv. 54 & $0.4 \mathrm{I}$ & $0.6 I$ & $2 \cdot 47$ \\
\hline IO. v. 54 & 0.14 & 0.40 & 0.39 \\
\hline I9. v: 54 & 0.19 & 0.36 & 0.63 \\
\hline 22. vi. 54 & 0.21 & 0.37 & $I \cdot I O$ \\
\hline I9. vii. 54 & 0.23 & $0.4 \mathrm{I}$ & $I \cdot 32$ \\
\hline II. viii. 54 & 0.24 & 0.45 & I.54 \\
\hline I4. ix. 54 & 0.26 & 0.44 & $2 \cdot 6 \mathrm{I}$ \\
\hline II. x. 54 & 0.34 & 0.46 & $2 \cdot 95$ \\
\hline II. xi. 54 & $0.4 \mathrm{I}^{\star}$ & $0.55^{\star}$ & $2 \cdot 94^{\star}$ \\
\hline 21. xii. 54 & $0.53^{\star}$ & $0.64 t$ & 3.7it \\
\hline
\end{tabular}

\section{INTEGRAL MEAN CONCENTRATIONS}

Computed figures are shown in Table II, and need little comment. The decreases representing consumption of nutrients in the spring outburst of plants were: phosphate $0.37 \mu \mathrm{g}$ atom $\mathrm{P} / 1$., total phosphorus $0.26 \mu \mathrm{g}$ atom $\mathrm{P} / 1$, silicate $2 \cdot 49 \mu \mathrm{g}$ atom $\mathrm{Si} / 1$.

\section{SUMMARY}

The results of analyses of water from the International Hydrographic Station E I during I954 are discussed. The seasonal variation is shown, in which it appears that consumption of nutrients in the spring outburst of plants was: phosphate $0.37 \mu \mathrm{g}$ atom $\mathrm{P} / 1$, total phosphorus $0.26 \mu \mathrm{g}$ atom $\mathrm{P} / 1$., silicate $2 \cdot 49 \mu \mathrm{g}$ atom Si/1., these figures being means for the whole water column. Unusual changes in silicate concentrations between January and February, 
and between August and September, are ascribed to changes in the water mass at the station. This conclusion is supported by the temperature, salinity and phosphate observations.

\section{REFERENCE}

Armstrong, F. A. J., I954. Phosphorus and silicon in sea water off Plymouth during the years I950 to I953. F. Mar. biol. Ass. U.K., Vol. 33, pp. 38I-92. 